\title{
Czy istnieją kontrowersje w leczeniu dyslipidemii?
}

\section{Are there any controversies in dyslipidemia treatment?}

\author{
Marcin Tomasz Wełnicki
}

III Klinika Chorób Wewnętrznych i Kardiologii Warszawskiego Uniwersytetu Medycznego

\section{ABSTRACT}

Artykuł stanowi omówienie wykładu pod tym samym tytułem wygłoszonego przez autora podczas X Jubileuszowej Konferencji Choroby Serca i Naczyń w grudniu 2018 roku w Sopocie. W artykule wskazano potencjalnie kontrowersyjne aspekty intensywnej terapii hipolipemizującej, odnosząć się między innymi do nowych, rygorystycznych kryteriów wyrównania gospodarki lipidowej w populacji pacjentów obciążonych najwyższym ryzykiem sercowo-naczyniowym. Skomentowano także obawy dotyczące wpływu terapii dyslipidemii na procesy kognitywne, ryzyko nowotworzenia oraz ryzyko wystąpienia zaburzeń gospodarki węglowodanowej.

Choroby Serca i Naczyń 2019, 16 (1), 58-61

Słowa kluczowe: dyslipidemia, cholesterol frakcji LDL, inhibitory PCSK9

\section{ABSTRACT}

The article is a revive of lecture performed during the X Conference Choroby Serca i Naczyń in December 2018 in Sopot. In the article some controversy aspects of aggressive treatment of dyslipidemia are mentioned. Author refer to new, more strict criteria of lowering LDL-cholesterol in patients with the highest cardiovascular risk.

Adres do korespondencji:

dr n. med. Marcin Tomasz Wełnicki

III Klinika Chorób Wewnętrznych i Kardiologii

Warszawski Uniwersytet Medyczny

ul. Kondratowicza 8, 03-242 Warszawa

e-mail:welnicki.marcin@gmail.com
Fears about the influence of dyslipidemia treatment on cognitive impairment, cancer development and the risk of carbohydrates metabolism are also discuss.

Choroby Serca i Naczyń 2019, 16 (1), 58-61

Key words: dyslipidemia, LDL-cholesterol, PCSK9 inhibitors

Terapia zaburzeń lipidowych to jeden z filarów kardiologii XXI wieku, jego budowę rozpoczęto jednak już ponad 100 lat temu. Cholesterol po raz pierwszy z kamieni żółciowych wyizolował w 1784 roku francuski lekarz i chemik François Poulletier. Kilka lat później Michel E. Chevreul zaproponował nazwę cholesterine, co z greki miało oznaczać stałą żółć ('chole' — żółć, 'stereos' twarda, stała). Kolejne dekady to kolejne przełomowe odkrycie dotyczące cholesterolu i jego znaczenia dla chorób serca i naczyń. W 1910 roku Windaus zauważył, że w ścianie zmiażdżycowanej aorty stężenie cholesterolu jest 20-krotnie wyższe niż w prawidłowym naczyniu. Kilka lat później Aniczkow dowiódł na modelu zwierzęcym, że dieta wysokocholesterolowa prowadzi do tworzenia się blaszek miażdżycowych. Badania dotyczące znaczenia hipercholesterolemii u ludzi na dużą, naukową skalę rozpoczęły się jednak dopiero w drugiej połowie XIX wieku. Dwa z nich, Seven Countries Study i Framingham Heart Study, stanowią fundament dzisiejszej kardiologii. Wreszcie na przełomie lat 70. i 80. ubiegłego wieku, w pracowni profesora Akira Endo, wyizolowano pierwsze inhibitory hydroksymetyloglutarylo-koenzymu A (HMG-CoA, hydroxy-methylglutaryl coenzyme a). Można śmiało powiedzieć, że statyny dla kardiologii okazały się tym, 
czym antybiotyki i szczepionki dla profilaktyki i terapii chorób zakaźnych [1].

Są jednak osoby, które negują ponad stuletni dorobek naukowy wielu badaczy. Podają w wątpliwość związek cholesterolu z epidemiologią chorób układu sercowo-naczyniowego, głoszą również, że lekarze uprawiający medycynę zgodnie ze sztuką, najlepsza swoją wiedzą i aktualnymi wytycznymi medycyny opartej na dowodach naukowych (EBM, evidence-based medicine) są tak naprawdę w zmowie z Big Pharma i działają na szkodę pacjentów. „Ukryte terapie” Jerzego Zięby czy „Mity o cholesterolu” Waltera Hartenbacha cieszą się ogromnym zainteresowaniem naszych pacjentów. Można oczywiście zignorować ten fakt, przypominając chociażby istnienie ruchu płaskoziemców - stowarzyszenia negującego teorię kopernikańską i utrzymującego, że Ziemia jest płaskim dyskiem. Ostatecznie każdy ma prawo do własnych poglądów tak długo, jak długo nie krzywdzi to innej osoby. Jednakże, nie reagując na zarzuty przeciwników statyn, podobnie jak nie reagując na aktywność ruchów antyszczepionkowych, ryzykujemy, że ta krzywda zostanie jednak wyrządzona i to w skali populacyjnej. Dlaczego? Ponieważ przeciwnicy statyn i obrońcy cholesterolu sięgają po potężną broń — mit.

Mitów nie wolno lekceważyć. Przez stulecia to właśnie mity zawierały wyobrażenia o świecie, kształtowały interpretację rzeczywistości i stanowiły element więzi społecznej. W XXI wieku mit definiuje się jako zbiorowe wyobrażenie, pozbawione racjonalnego uzasadnienia, wynikające z emocji i pragnień określonej wspólnoty, ale jednocześnie modelujące ludzkie zachowanie. Mity kreowanei propagowane przez ruchy antyszczepionkowe czy przeciwników statyn mają jeden wspólny wątek, jaki jest hasło: „lekarze kłamią". To jest właśnie główny powód, dla którego należy z nimi walczyć. Skutki zdrowotne utraty zaufania pacjentów do lekarzy są trudne do oszacowania. Powstaje jednak pytanie, jak mamy walczyć z naszymi adwersarzami? Et cognoscetis veritatem, et veritas liberabit vos - poznajcie prawdę, a prawda was wyzwoli. Zastanówmy się więc, które z założeń nowoczesnej terapii hipercholesterolemii mogą się wydawać kontrowersyjne i spróbujmy zmierzyć się z wątpliwościami.

Ostatnio ukazały się rekomendacje dotyczące leczenia dyslipidemii w Polsce - III Deklaracja Sopocka. Tradycyjnie już dokument ten jest bardzo progresywny. Zaproponowano w nim nowy podział ryzyka sercowo-naczyniowego oraz nowe, bardzo rygorystyczne, cele leczenia dyslipidemii [2]. Do grupy ekstremalnie wysokie ryzyka zakwalifikowano chorych:

- po wielokrotnych incydentach sercowo-naczyniowych i/lub rewaskularyzacjach;

- po przezskórnym stentowaniu pnia głównego lewej tętnicy wieńcowej lub/i z wielonaczyniową chorobą wieńcową (kompleksowa angioplastyka w wielonaczyniowej chorobie wieńcowej);

- z miażdżycą uogólnioną — wielu łożysk naczyniowych ze współistniejącymi dodatkowymi czynnikami ryzyka;

- z progresją choroby układu sercowo-naczyniowego o podłożu miażdżycowym u pacjentów, u których osiągnięto i stale utrzymywano stężenie cholesterolu frakcji LDL (low-density lipoprotein) poniżej $55 \mathrm{mg} / \mathrm{dl}$ $(<1,4 \mathrm{mmol} / \mathrm{l})$.

Wszyscy zapewne zgodzimy się co do zasadności wyodrębnienia takiej grupy. Cel leczenia, który dla niej zdefiniowano, tj. stężenie cholesterolu frakcji LDL poniżej $35 \mathrm{mg} / \mathrm{dl}$, może już jednak stanowić przedmiot kontrowersji. Czy istnieją jakikolwiek rzeczywiste obawy dotyczące ekstremalnie intensywnego leczenia hipolipemizującego? Czy nie obawiamy się zaburzenia procesów fizjologicznych, cukrzycy, neurodegeneracji, nowotworzenia, zwiększenia częstości ciężkich uszkodzeń wątroby lub mięśni? Przyjrzyjmy się po kolei tym problemom.

Silne statyny, terapia skojarzona oraz inhibitory konwertazy proproteinowej subtilizyny/keksyny typu 9 (PCSK9, proprotein convertase subtilisin/kexin type 9) wprowadzają nas w nowe regiony możliwości leczenia dyslipidemii. W pewnym sensie pozwalają cofnąć czas, odmłodzić się metabolicznie i uzyskać stężenie cholesterolu frakcji LDL niższe nawet niż w przypadku nowo narodzonych dzieci. A cholesterol jest przecież potrzeby do syntezy żółci, hormonów steroidowych czy błon komórkowych. Czy jest więc możliwe, aby go na nam zabrakło? Wątpliwe. Stężenie cholesterolu frakcji LDL w płynie zewnątrzkomórkowym stanowi tylko 20\% osoczowego stężenia LDL. Komórki wymagające cholesterolu do wykonywania swoich funkcji są wyposażone w większą niż pozostałe liczbę receptorów dla LDL i skutecznie, dynamicznie regulują jego pobieranie. Wydaje się, że stężenie LDL w płynie zewnątrzkomórkowym bezpieczne dla większości komórek to 2,5 mg/dl. Oznacza to, że — hipotetycznie - stężenie osoczowe wynoszące $12,5 \mathrm{mg} / \mathrm{dl}$ w zupełności powinno wystarczyć [3]. Pierwszą, fizjologiczną kontrowersję można zatem uznać za wyjaśnioną. 
Kolejna obawa dotyczy ryzyka wystąpienia cukrzycy. Nie jest to obawa bezzasadna. $Z$ wielu badań wiedomo, że statyny zwiększają ryzyko wystąpienia nowych przypadków cukrzycy typu 2. Patomechanizm tego zjawiska nie jest jasny, tym bardziej że u osób już na cukrzycę chorujących statyny nie pogarszają kontroli gospodarki węglowodanowej i poprawiają rokowanie sercowo-naczyniowe. Warto także przypomnieć, że w przypadku pacjenta bez cukrzycy, ale ze wskazaniami do stosowania statyny, niezależnie od stężenia cholesterolu frakcji LDL, rachunek zysków i strat w kontekście ryzyka działania prodiabetogennego przemawia jednoznacznie za stosowaniem leków z tej grupy [4]. Mamy wreszcie subanalizy badania Fourier wskazujące na brak zwiększenia ryzyka występowania nowych przypadków cukrzycy oraz brak wpływu na wyrównanie gospodarki węglowodanowej u osób z już rozpoznaną cukrzycą stosujących ewolokumab, inhibitor PCSK9 [5]. W praktyce osiągnięcie stężenia cholesterolu frakcji LDL poniżej $35 \mathrm{mg} / \mathrm{dl}$ wiąże się z koniecznością stosowania terapii skojarzonej, statyny i przynajmniej ezetimibu lub nawet inhibitora PCSK9 właśnie. W świetle przeprowadzonych dotychczas badań należy uznać, że taka intensyfikacja nie zaburzy procesu leczenia chorych na cukrzycę, a u osób wolnych od tego schorzenia nie zwiększy dodatkowo ryzyka jej wystąpienia.

Intensywne leczenie hipolipemizujące wydaje się również bezpieczne w kontekście ryzyka występowania zaburzeń procesów poznawczych. Ten temat wzbudza jednak chyba najwięcej kontrowersji. Badania obserwacyjne wskazują jednocześnie na obniżenie ryzyka występowania choroby Alzheimera i otępienia wielonaczyniowego oraz na wzrost ryzyka przemijających zaburzeń poznawczych u osób przyjmujących statyny. Żadnego z powyższych jednak dotychczas nie dowiedziono w prospektywnych badaniach randomizowanych. Sugeruje się, że korzystny wpływ statyn na funkcję procesów poznawczych może wynikać z przywrócenia prawidłowej homeostazy lipidowej w neurocytach. Z jednej strony wykryto między innymi, że niektóre genotypy HMG-CoA sprzyjają występowaniu otępienia typu alzheimerowskiego. Z drugiej jednak strony silne i lipofilne statyny mogą zaburzeń transport cholesterolu w neurocytach i w tym mechanizmie negatywnie wpływać na procesy kognitywne. Możliwe, że ważną rolę pełnią w tym przypadku niedobory koenzymu Q10 [6]. Z całą pewnością to zagadnienie wymaga dalszych badań, naukowcy zga- dzają się jednak co do tego, że obawa przed hipotetyczną możliwością odwracalnego pogorszenia procesów poznawczych nie może być argumentem przeciwko stosowaniu statyn $\mathrm{w}$ kardiologii.

Niepokój w kontekście nowych metod leczenia zaburzeń lipidowych pojawił się po publikacji metaanalizy Khan i wsp. [7]. Sugerowali oni, że stosowanie inhibitorów PCSK9 zwiększa ryzyko schorzeń neurodegeneracycjnych niemal 3-krotnie (iloraz szans [OR, odds ratio] 2,85; 95-proc. przedział ufności [CI, confidence interval] 1,34-6,06). W tej metaanalizie uwzględniono jednak tylko dwa badania kliniczne, a bezwzględna liczba przypadków z neurodegeneracją była bardzo mała $(<1 \%)$. Z całą pewnością wielu informacji na ten temat dostarczy trwające jeszcze badanie ODYSSEY outcome. W jego protokole założono uzyskanie najliczniejszej grupy pacjentów ze stężeniem cholesterolu frakcji LDL poniżej $50 \mathrm{mg} / \mathrm{dl}$ przy jednoczesnej minimalizacji liczby pacjentów z tym stężeniem mniejszym niż $15 \mathrm{mg} / \mathrm{dl}$ [8]. Tymczasem dysponujemy już wynikami subanaliz badania Fourier, przedstawionych podczas kongresu Europejskiego Towarzystwa Kardiologicznego (ESC, European Society of Cardiology) w sierpniu 2017 roku, w Barcelonie. Analiza występowania działań niepożądanych w poszczególnych przedziałach stężenia LDL ( $<20$ mg/dl, 20-49 mg/dl, 50-69 mg/ /dl, 70-99 mg/dl, > $100 \mathrm{mg} / \mathrm{dl}$ ) nie wykazała żadnych istotnych różnic w zakresie ryzyka wystąpienia zaburzeń procesów poznawczych. Jednocześnie nie zaobserwowano różnic pod względem ryzyka wystąpienia nowych przypadków cukrzycy, zaćmy, nowotworów, uszkodzenia mięśni czy wątroby ani udarów krwotocznych [9].

Kontrowersje dotyczące leczenia zaburzeń lipidowych są, zapewne będą i prawdopodobnie pojawią się nowe. To bardzo dobrze; umysł jest mieczem, który ostrzy się w ogniu dyskusji. W dziedzinie wiedzy brak postępu to nie stagnacja, ale regres. Nie bójmy się więc pytań; zadawajmy je sami, nie obrażajmy się na krytykę. Argumentujmy nasze racje. Jeśli nie potrafimy prosto uzasadnić naszych decyzji terapeutycznych, to pojawia się wątpliwość, czy sami do końca je rozumiemy. Jak mamy więc wówczas przekonać innych, naszych pacjentów, do swojego zdania?

\section{KONFLIKT INTERESÓW}

Honoraria za wykłady/szkolenia/udział w konferencjach firm: Egis, Krka, Teva, Novartis, Sanofi-Aventis, Sandoz, Bayer, Boehringer Ingelheim, Pfizer. 


\section{PIŚMIENNICTWO}

1. Endo A. A historical perspective on the discovery of statins. Proc Jpn Acad Ser B Phys Biol Sci. 2010; 86(5): 484-493, indexed in Pubmed: 20467214.

2. Wożakowska-Kapłon B, Filipiak K, Mamcarz A, et al. Aktualne problemy terapii dyslipidemii w Polsce — II Deklaracja Sopocka. Stanowisko grupy ekspertów wsparte przez Sekcję Farmakoterapii Sercowo-Naczyniowej Polskiego Towarzystwa Kardiologicznego. Kardiol Pol. 2014; 72(9): 847-853, doi: 10.5603/kp.2014.0182.

3. Olsson AG, Angelin B, Assmann G, et al. Can LDL cholesterol be too low? Possible risks of extremely low levels. J Intern Med. 2017; 281 (6): 534-553, doi: 10.1111/joim.12614, indexed in Pubmed: 28295777.

4. Sattar N, Preiss D, Murray HM, et al. Statins and risk of incident diabetes: a collaborative meta-analysis of randomised statin trials. Lancet. 2010; 375(9716): 735-742, doi: 10.1016/S0140-6736(09)61965-6, indexed in Pubmed: 20167359

5. Sabatine MS, Leiter L, Wiviott S, et al. Cardiovascular safety and efficacy of the PCSK9 inhibitor evolocumab in patients with and without diabetes and the effect of evolocumab on glycaemia and risk of new-onset diabetes: a prespecified analysis of the FOURIER randomised controlled trial. Lancet Diabetes Endocrinol. 2017; 5(12): 941-950, doi: 10.1016/s2213-8587(17)30313-3.

6. Schultz BG, Patten DK, Berlau DJ. The role of statins in both cognitive impairment and protection against dementia: a tale of two mechanisms. Transl Neurodegener. 2018; 7: 5, doi: 10.1186/s40035-0180110-3, indexed in Pubmed: 29507718.

7. Khan AR, Bavishi C, Riaz H, et al. Increased risk of adverse neurocognitive outcomes with proprotein convertase subtilisin-kexin type 9 inhibitors. Circ Cardiovasc Qual Outcomes. 2017; 10(1), doi: 10.1161/CIRCOUTCOMES.116.003153, indexed in Pubmed: 28073851.

8. Schwartz GG, Bessac L, Berdan LG, et al. Effect of alirocumab, a monoclonal antibody to PCSK9, on long-term cardiovascular outcomes following acute coronary syndromes: rationale and design of the ODYSSEY outcomes trial. Am Heart J. 2014; 168(5): 682-689, doi: 10.1016/j.ahj.2014.07.028, indexed in Pubmed: 25440796.

9. Giugliano RP. ESC Congress 2017, Barcelona 8/28/2017. 
